\title{
Pengaruh Kompensasi Sumber Daya Manusia, Motivasi dan Lingkungan Kerja Terhadap Kinerja Aparatur Sipil Negara
}

\author{
Dina Gumay Putri ${ }^{1}$, Darius Antoni ${ }^{2}$ \\ Universitas Bina Darma Palembang \\ dinagumayputri@gmail.com¹, darius.antoni@binadarma.ac.id ${ }^{2}$
}

\begin{abstract}
The purpose of this study was to analyze the effect of compensation for human resources, work motivation, work environment on the work performance of the apparatus at the Department of Culture and Tourism of the Government of South Sumatra Province. In this study, the population was employees of the Department of Culture and Tourism of the Government of South Sumatra Province. In this study, the sampling technique used was a saturated sample. The number of samples is 45 people. The analysis technique used is multiple regression analysis. The results of the first hypothesis (H1) indicate that HR compensation has a positive and significant effect on employee performance. Employees have received HR compensation in accordance with the results of their performance so that employees will work responsibly and in accordance with established operational standards. The results of the second hypothesis (H2) indicate that work motivation has a positive and significant effect on employee performance. Employees' work motivation will improve employee performance to achieve company goals. The results of the third hypothesis (H3) indicate that the work environment has a positive and significant effect on employee performance. A working environment condition is said to be good if employees can carry out activities optimally, healthy, safe, and comfortable. Therefore, the determination and creation of a good work environment will greatly determine the success of achieving organizational goals. Simultaneous testing of HR compensation (X1), Work Motivation (X2), Work Environment (X3) on Employee Performance (Y) Ha is accepted, meaning that it shows that there is a positive and significant influence on HR Compensation, Motivation and Work Environment together ( Simultaneous) on the Performance variable at the Culture and Tourism Office of South Sumatra Province.
\end{abstract}

Keywords: human resources, work motivation, work environment on the work performance

\section{Introduction}

Aparatur sebagai elemen penting organisasi pemerintah Sebagai elemen penting dalam organisasi, menurut Hasibuan (2011:10) manajemen sumber daya manusia adalah ilmu dan seni mengatur hubungan dan peranan tenaga kerja agar efektif dan efisien, membantu terwujudnya tujuan perusahaan, karyawan dan masyarakat. Sedangkan menurut Simamora (2006 : 4) manajemen sumber daya manusia adalah, pendayagunaan, pengembangan, penilaian, pemberian balas jasa, dan pengelolaan individu anggota organisasi atau kelompok karyawan, juga menyangkut desain dan implementasi sistem perencanaan, penyusunan karyawan, pengembangan karyawan, pengelolaan karir, evaluasi kinerja, kompensasi karyawan dan hubungan ketenagakerjaan yang baik. Dalam menjamin tercapainya kinerja pegawai pemerintahan memberikan perhatian dengan memberikan kompensasi, karena kompensasi merupakan hubungan timbal balik antara organisasi dengan sumberdaya manusia, besarnya kompensasi merupakan pencerminan atau ukuran nilai pekerjaan karyawan itu dan kepuasan kerja karyawan.

Pemberian kompensasi dapat meningkatkan prestasi kerja dan memotivasi karyawan. Oleh karena itu, perhatian organisasi atau perusahaan terhadap pengaturan kompensasi secara 
rasional dan adil sangat diperlukan. Bila karyawan memandang pemberian kompensasi tidak memadai, prestasi kerja, motivasi maupun kepuasan kerja mereka cenderung akan menurun (Samsudin, 2010: 187). Menurut Mangkunegara (2009:84) kompensasi yang diberikan kepada pegawai sangat berpengaruh pada tingkat kepuasan kerja dan motivasi kerja. Menurut Malthis (2006:114), motivasi adalah keinginan dalam diri seseorang yang menyebabkan orang tersebut bertindak. Biasanya orang bertindak karena suatu alasan untuk mencapai tujuan. Motivasi dari dalam diri pegawai dapat berasal dari kebutuhan akan uang, penghargaan, kekuasaan, dan pengakuan. Motivasi dari luar dapat berasal dari keluarga, teman kerja maupun atasan.

Faktor lain yang mempengaruhi kinerja kerja pegawai dalam melaksanakan tugas adalah lingkungan kerja yaitu segala sesuatu yang ada di sekitar pekerja, yang dapat mempengaruhi dirinya dalam menjalankan tugas (Nitisemito, 2001). Faktor lingkungan kerja bisa berupa kondisi fisik kantor yang meliputi penerangan, suhu udara, dll yang mampu meningkatkan suasana kondusif dan semangat kerja serta berpengaruh terhadap kinerja pegawai (Sedarmayanti, 2001). Menurut Mangkunegara (2006) lingkungan kerja meliputi uraian jabatan yang jelas, autoritas yang memadai, target kerja yang menantang, pola komunikasi, hubungan kerja yang harmonis, iklim kerja yang dinamis, peluang karir, dan fasilitas kerja yang memadai. Lingkungan kerja yang tidak memuaskan dapat menurunkan semangat kerja dan akhirnya menurunkan produktifitas kerja pegawai (Ahyari, 1986).

Dinas Kebudayaan dan Pariwisata Provinsi Sumatera Selatan merupakan salah satu Organisasi Perangkat Daerah (OPD) teknis yang berada di bawah Pemerintahan Provinsi Sumatera Selatan, yang mempunyai tugas pokok melaksanakan urusan daerah di bidang Kebudayaan dan Pariwisata serta fungsi dinas sebagai perumusan kebijakan teknis, penyelenggaraan, pembinaan dan pelaksanaan tugas di bidang Kebudayaan dan Pariwisata. Berdasarkan hasil observasi yang dilakukan penulis pada Dinas Kebudayaan dan Pariwisata Provinsi Sumatera Selatan terdapat beberapa permasalahan yang berhubungan dengan kinerja yang ditunjukkan oleh para pegawai yang bekerja disana. Dilihat dari sudut pandang peneliti dan wawancara pegawai, beberapa masalah tersebut di sebabkan oleh beberapa faktor yang cukup kompleks yaitu faktor kompensasi sumber daya manusia yang menyebabkan kurang nya motivasi pegawai dan faktor lingkungan kerja di instansi tersebut. Pada banyak aktivitas atau kegiatan kerja tidak sepenuhnya diberikan kompensasi yang layak kepada seluruh pegawainya, hal ini terjadi karena tidak tersedianya anggaran Dinas Kebudayaan dan Pariwisata Provinsi Sumatera Selatan sehingga menyebabkan kurang nya motivasi dalan bekerja dalam menyelesaikan tugasnya kurang optimal.

Selanjutnya dari segi lingkungan kerja, permasalahan yang cenderung terjadi yaitu fasilitas di lingkungan Dinas Kebudayaan dan Pariwisata Provinsi Sumatera Selatan yang kurang memadai untuk para pegawai yang bekerja di Dinas tersebut. Fasilitas tersebut meliputi penempatan ruang kerja yang kurang tertata dengan baik, permasalahn kapasitas ruangan penyimpanan arsip yang menjadi satu dalam ruang kerja pegawai yang kecil sehingga ruang aktivitas pegawai yang kurang untuk bergerak. Demikian pula dapat di lihat dari pembagian tugas kepada bawahan, masih belum sesuai dengan tugas pokok dan fungsi pegawai tersebut dikarenakan mengalami kendala dalam menyelesaikan tugas-tugas yang diberikan sehingga kinerjanya menjadi turun dan cenderung mengalami beban kerja yang berlebih.

\section{Literature Review}




\subsection{Manajemen Sumber Daya Manusia}

Menurut Hasibuan (2014:10) bahwa manajemen sumber daya manusia adalah ilmu dan seni mengatur hubungan dan peranan tenaga kerja agar efektif dan efisien membantu terwujudnya tujuan perusahaan, karyawan, dan masyarakat. Rivai dan Sagala (2013:18) menyatakan bahwa manajemen sumber daya manusia merupakan salah satu dari bidang manajemen umum yang meliputi segi-segi perencanaan, pengorganisasian, pelaksanaan dan pengendalian, sumber daya manusai dalam sebuah organisasi. Tujuan MSDM adalah meningkatkan kontribusi produktif orang-orang yang ada dalam perusahaan melalui sejumlah cara yang bertanggung jawab secara strategis, etis, dan sosial (Veithzl Rivai, 2015:8). Fungsi sumber daya manusia meliputi (Hasibuan, 2014:21) adalah Perencanaan, Pengorganisasian, Pengarahan, Pengendalian. Pengadaan, Pengembangan, Kompensasi, Pengintegrasian. Pemeliharaan, Kedisiplinan, Pemberhentian.

\subsection{Kompensasi}

Menurut (Hasibuan, 2010: 118), kompensasi adalah semua pendapatan yang berbentuk uang, barang langsung atau tidak langsung yang diterima karyawan sebagai imbalan atas jasa yang diberikan kepada perusahaan. Kompensasi adalah segala sesuatu yang diterima para karyawan sebagai balas jasa untuk kerja mereka.(Handoko, 2012: 155). Kompensasi adalah semua pendapatan yang berbentuk uang, barang langsung atau tidak langsung yang diterima karyawan sebagai imbalan atas jasa yang diberikan kepada perusahaan. Kompensasi sangat penting bagi karyawan itu sendiri sebagai individu, karena besarnya kompensasi merupakan cerminan nilai bagi karyawan itu sendiri. Besar kecilnya kompensasi dapat mempengaruhi kinerja karyawan dan kepuasan kerja karyawan (Roihatul Musyafi. Et.al, 2016).

Menurut Veithzal rivai (2009:744), komponen- komponen kompensasi sebagai berikut :

1) Gaji adalah balas jasa dalam bentuk uang yang diterima karyawan sebagai konsekuensi dari kedudukannya sebagai seorang karyawan sebagai seorang karyawan yang memberikan sumbangan tenaga dan fikiran dalam mencapai tujuan perusahaan.

2) Upah merupakan imbalan finansial langsung yang dibayarkan kepada karyawan berdasarkan jam kerja, jumlah barang yang dihasilkan atau banyaknya pelayanan yang diberikan.

3) Insentif merupakan imbalan langsung yang dibayarkan kepada karyawan karena kinerjanya melebihi yang standar yang ditentukan. Insentif merupakan bentuk lain dari upah langsung diluar upah dan gaji yang merupakan kompensasi tetap, yang biasa disebut kompensasi berdasarkan kinerja.

Tujuan pemberian kompensasi (Ike Kusdiyah Rachmawati 2008:144):

1. Mendapatkan karyawan yang berkualitas.

2. Mempertahankan karyawan yang sudah ada.

3. Adanya keadilan.

4. Perubahan sikap dan perilaku.

5. Efisiensi biaya Program kompensasi yang rasional membantu organisasi untuk mendapatkan dan mempertahankan sumber daya manusia pada tingkat biaya yang layak.

6. Administrasi legalitas 
Menurut (Gugup Kismono, 2011:177) dalam melaksanakan kebijakan kompensasi, perlu dikaji adanya peraturan tentang kompensasi dengan maksud agar dapat memberikan balas jasa kepada karyawan secara adil dan terstruktur sehingga akan memperlancar administrasi penggajian dan untuk memotivasi karyawan supaya berprestasi

\subsection{Motivasi}

Menurut Robbins dalam Wibowo (2016:322) mendefinisikan motivasi sebagai proses yang menyebabkan intensitas, arah, dan usaha terus menerus bagi individu menuju pencapaian tujuan. Menurut Kompri (2015:4) memberian definisi motivasi merupakan pendorong yang mengubah dalam energi seseorang dalam bentuk aktifitas nyata dalam mencapai tujuan tertentu. Motivasi adalah suatu dorongan dari dalam individu untuk melalukan suatu tindakan dengan cara tertentu sesuai dengan tujuan yang ingin direncanakan. Menurut Abdul Rahman Shaleh, Fungsi motivasi Fungsi motivasi adalah sebagai berikut:

a. Mendorong timbulnya kelakuan atau suatu perbuatan.

b. Motivasi berfungsi sebagai pengarah, artinya mengarahkan perbuatan kepencapaian tujuan yang diinginkan.

c. Motivasi berfungsi sebagai penggerak, artinya motivasi akan berfungsi sebagai penentu cepat lambanya suatu pekerjaan.

d. Motivasi berfungsi sebagai penolong untuk berbuat mencapai tujuan.

e. Penentu arah perbuatan manusia, yakni kearah yang akan dicapai.

f. Penyeleksi perbuatan, sehingga perbuatan manusia senantiasa selektif dan tetap terarah kepada tujuan yang ingin dicapai.

\subsection{Lingkungan Kerja}

Menurut Sedarmayanti (2011:11), Lingkungan kerja adalah keseluruhan alat perkakas dan bahan yang dihadapi, lingkungan sekitarnya dimana seseorang bekerja, metode kerjanya, serta pengaturan kerjanya baik sebagai perseorangan maupun sebagai kelompok. Menurut Danang Sunyoto (2015:38) lingkungan kerja adalah segala sesuatu yang ada disekitar para pekerja dan yang dapat mempengaruhi dirinya dalam menjalankan tugas-tugas yang dibebankan. Dalam penjelasan di atas dapat disimpulkan bahwa lingkungan kerja adalah kondisi disekitar Pegawai yang dapat mempengaruhi dirinya dalam menjalankan tugas yang dia emban atau yang menjadi tanggung jawabnya. Manfaat lingkungan kerja adalah menciptakan gairah kerja, sehingga produktivitas kerja meningkat.

Berikut beberapa indikator lingkungan kerja yang diuraikan Lestari dan Setiawan (2015) yaitu :

1. Kebersihan tepat kerja

2. Penerangan

3. Suhu Udara

4. Kelengkapan fasilitas kerja

5. Keamanan lingkungan kerja

6. Hubungan antara pimpinan dan bawahan

\section{$2.5 \quad$ Kinerja Pegawai}

Kinerja adalah keluaran yang dihasilkan oleh fungsi-fungsi atau indikator-indikator 
suatu pekerjaan atau suatu profesi dalam waktu tertentu (Wirawan, 2009: 5). Menurut Cherington dalam (Khaerul Uman, 2010 : 188) mengatakan bahwa kinerja menunjukkan pencapaian target kerja yang berkaitan dengan kualitas, kuantitas dan waktu. Menurut (Juavani, 2009 : 548-549), kinerja merupakan perilaku nyata yang ditampilkan setiap orang sebagai prestasi kerja yang dihasilkan oleh karyawan sesuai dengan peranannya dalam perusahaan.

Kinerja karyawan (prestasi kerja) adalah hasil kerja secara kualitas dan kuantitas yang dicapai oleh seorang karyawan dalam melaksanakan tugasnya sesuai dengan tanggung jawab yang diberikan kepadanya (Mangkunegara, 2007:67).

Ada dua faktor yang mempengaruhi kinerja karyawan, yaitu :

1) Faktor kemampuan Perlu penempatan karyawan pada pekerjaan yang sesuai dengan keahliannya

2) Faktor motivasi Kondisi yang menggerakan diri karyawan yang terarah untuk mencapai tujuan.Organisasi(tujuan kerja) yang merupakan dorongan yang timbul dari dalam diri karyawan untuk melakukan kegiatan atau tugas dengan sebaik-baiknya agar mampu mencapai prestasi kerja (kinerja) dengan predikat terpuji.(Mangkunegara, 2009 : 67-68).

Menurut steers dalam buku (Edi sutrisno, 2009:151) umumnya orang percaya bahwa prestasi kerja individu merupakan fungsi gabungan dari tiga faktor, yaitu :

1. Kemampuan, perangai, dan minat seorang pekerja.

2. Kejelasan dan penerimaan atas penjelasan peranan seseorang dalam bekerja.

3. Tingkat motivasi kerja.

Menurut Moeheriono (2012:114)) Indikator kinerja untuk setiap level organisasi, tergantung dari kompleksitas organisasi itu. organisasi tertentu dapat mengembangkan kategori masing-masing yang sesuai dengan misinya, yaitu sebagai berikut:

a) Efektif, indikator ini mengukur derajat kesesuaian output yang dihasilkan dalam mencapai sesuatu yang diinginkan. Indikator mengenai efektivitas ini menjawab pertanyaan mengenai apakah kita melakukan sesuatu yang sudah benar (are we doing the right thing?)

b) Efisien, indikator ini mengukur derajat kesesuaian proses menghasilkan output dengan menggunakan biaya serendah mungkin. Indikator mengenai efektivitas menjawab pertanyaan mengenai apakah kita melakukan sesuatu dengan benar (are we doing things right?)

c) Kualitas, indikator ini mengukur derajat kesesuaian antara kualitas produk atau jasa yang dihasilkan dengan kebutuhan dan harapan konsumen.

d) Ketepatan waktu, indikator ini mengukur apakah pekerjaan telah diselesaikan secara benar dan tepat waktu. Untuk itu, perlu ditentukan kriteria yang dapat mengukur berapa lama waktu yang seharusnya diperlukan untuk menghasilkan suatu produk.

e) Produktivitas, indikator ini mengukur tingkat produktivitas suatu organisasi.

f) Keselamatan, indikator ini mengukur kesehatan organisasi secara keseluruhan serta lingkungan kerja para pegawainya ditinjau dari aspek keselamatan. 


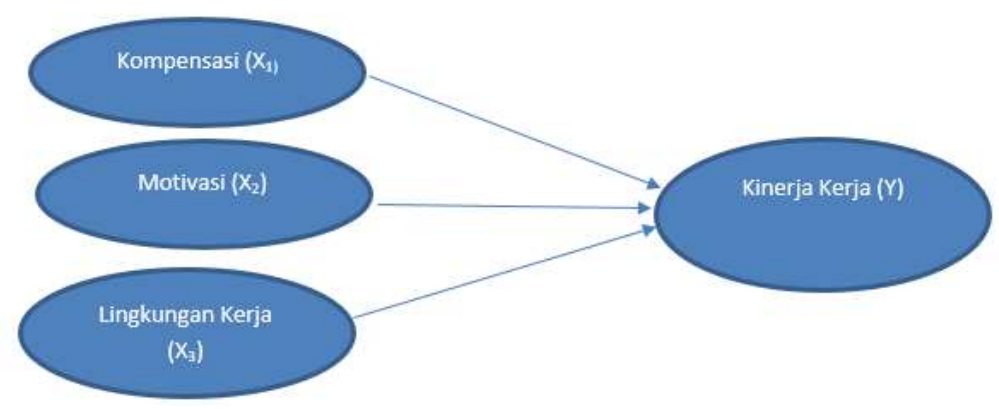

Gambar 1. Kerangka Pemikiran

Hipotesis dalam penelitian ini adalah sebagai berikut:

1. H1 : Kompensasi Sumber Daya Manusia berpengaruh terhadap kinerja pegawai pada Dinas Kebudayaan dan Pariwisata Pemerintah Provinsi Sumatera Selatan

2. H2 : Motivasi Kerja berpengaruh terhadap kinerja pegawai pada Dinas Kebudayaan dan Pariwisata Pemerintah Provinsi Sumatera Selatan.

3. H3 : Lingkungan kerja berpengaruh terhadap kinerja Pegawai pada Dinas Kebudayaan dan Pariwisata Pemerintah Provinsi Sumatera Selatan.

\section{Research Method}

Objek penelitian dalam penelitian ini adalah Dinas Kebudayaan dan Pariwisata Provinsi Sumatera Selatan Dalam penelitian ini populasinya adalah pegawai Dinas Kebudayaan dan Pariwisata Pemerintah Provinsi Sumatera Selatan. Dalam penelitian ini teknik pengambilan sampel yang digunakan adalah sampel jenuh. Sampel jenuh adalah teknik penentuan sampel bila semua anggota populasi digunakan sebagai sampel (Sugiyono, 2011). Jumlah Sampel sebanyak 45 orang.

Jenis dan Sumber Data menggunakan sumber data primer, dalam penelitian ini, pengambilan data dilakukan dengan cara menyebar kuesioner kepada pegawai pada Dinas kebudayaan dan Pariwisata pemerintah provinsi Sumatera Selatan. Kuesioner tersebut disebar guna memperoleh data mengenai sejauh mana variabel bebas yaitu kompensasi, motivasi dan lingkungan kerja dapat mempengaruhi kinerja pegawai. dan sumber data sekunder, melalui dokumen dan Sumber data yang digunakan untuk mendukung penelitian ini didapat dari berbagai artikel, buku, dan beberapa penelitian terdahulu dari berbagai sumber yang berhubungan dengan penelitian ini.

Teknik Analisis data dalam penelitian ini dilakukan dengan beberapa tahapan yaitu diawali uji kualitas data dengan uji validitas dan Reliabilitas data. Kemudian dilanjutkan analisis regresi linier berganda dan uji hipotesisn, uji signifikansi parsial (uji-t) dan yang terakhir uji signifikansi simultan (uji-F).

\section{Findings and Discussions}

\subsection{Uji Kualitas Data}

Keabsahan dari hasil penelitian sangat ditentukan oleh data yang dihasilkan adri alat ukur yang digunakan. Untuk menguji apakah instrument yang digunakan memenuhi syaratsyarat alat ukur yang baik atau tidak, sehingga menghasilkan data yang sesuai dengan apa 
yang diukur. Sebelum dilakukan analisis data berdasarkan hasil kuesioner yang terkumpul terlebih dahulu dilakukan uji validitas dan reabilitas data.

\subsubsection{Uji Validitas}

Uji Validitas merupakan suatu ukuran yang menunjukkan kevalidan dari sebuah kuesioner. Menurut Fauzi, Dencik, \& Asiati (2019) apabila nilai Corrected Item-Total Correlation (R- Hitung) $>$ R- Tabel maka kuesioner yang disusun valid. Namun apabila didapat nilai R-Hitung $<$ R-Tabel maka kuesioner yang disusun tidak valid, pada penelitian ini R-Tabel yang digunakan sebesar 0, 294 yang selanjutnya dibandingkan dengan nilai R-Hitung pada item-item pernyataan yang ada pada setiap variabel.

Tabel 1.Uji Validitas

\begin{tabular}{|c|c|c|c|c|}
\hline Variabel & Pernyataan & $r$ hitung & r tabel & Keterangan \\
\hline \multirow{8}{*}{$\begin{array}{c}\text { Kompensasi } \\
\text { SDM } \\
\left(\mathrm{X}_{1}\right)\end{array}$} & 1 & 0,556 & \multirow[t]{8}{*}{0,294} & Valid \\
\hline & 2 & 0,481 & & Valid \\
\hline & 3 & 0,378 & & Valid \\
\hline & 4 & 0,583 & & Valid \\
\hline & 5 & 0,431 & & Valid \\
\hline & 6 & 0,552 & & Valid \\
\hline & 7 & 0,613 & & Valid \\
\hline & 8 & 0,534 & & Valid \\
\hline \multirow{8}{*}{$\begin{array}{l}\text { Motivasi } \\
\left(\mathrm{X}_{2}\right)\end{array}$} & 1 & 0,801 & \multirow[t]{8}{*}{0,294} & Valid \\
\hline & 2 & 0,840 & & Valid \\
\hline & 3 & 0,308 & & Valid \\
\hline & 4 & 0,352 & & Valid \\
\hline & 5 & 0,780 & & Valid \\
\hline & 6 & 0,679 & & Valid \\
\hline & 7 & 0,732 & & Valid \\
\hline & 8 & 0,505 & & Valid \\
\hline \multirow{8}{*}{$\begin{array}{c}\text { Lingkungan } \\
\text { Kerja } \\
\left(\mathrm{X}_{3}\right)\end{array}$} & 1 & 0,585 & \multirow[t]{8}{*}{0,294} & Valid \\
\hline & 2 & 0,860 & & Valid \\
\hline & 3 & 0,776 & & Valid \\
\hline & 4 & 0,594 & & Valid \\
\hline & 5 & 0,505 & & Valid \\
\hline & 6 & 0,704 & & Valid \\
\hline & 7 & 0,746 & & Valid \\
\hline & 8 & 0,816 & & Valid \\
\hline \multirow{8}{*}{$\begin{array}{l}\text { Kinerja } \\
\text { (Y) }\end{array}$} & 1 & 0,595 & \multirow[t]{8}{*}{0,294} & Valid \\
\hline & 2 & 0,735 & & Valid \\
\hline & 3 & 0,476 & & Valid \\
\hline & 4 & 0,654 & & Valid \\
\hline & 5 & 0,676 & & Valid \\
\hline & 6 & 0,546 & & Valid \\
\hline & 7 & 0,899 & & Valid \\
\hline & 8 & 0,842 & & Valid \\
\hline
\end{tabular}

Sumber : Data yang diolah penulis, 2021

Hasil pengujian validitas kuesioner diatas menunjukkan bahwa seluruh item pernyataan r-Hitung lebih besar dari r-Tabel. Sehingga dapat dikatakan bahwa item kuesioner variabel X1, X2, X3, dan Y dapat digunakan untuk mengukur variabel yang diteliti.

\subsubsection{Uji Reliabilitas}

Setelah diperoleh hasil kuesioner yang digunakan dalam penelitian ini valid, dilanjutkan dengan uji reliabilitas. Menurut Sugiono (2005), reliabilitas adalah serangkaian 
pengukuran atau serangkaian alat ukur yang memiliki konsistensi jika pengukuran yang dilakukan dengan alat ukur itu dilakukan secara berulang. Reliabilitas tes adalah tingkat konsistensi suatu tes, yaitu sejauhmana tes bisa dipercaya untuk menghasilkan skor yang konsisten, relatif tidak berubah meskipun diteskan pada situasi yang berbeda. Hasil perhitungan koefisien reliabilitas dapat dilihat pada. Apabila Uji Reliabilitas Cronbach's Alpha $>$ dari r-tabel maka butir variabel telah reliable. Tapi jika Cronbach's Alpha $<$ dari rtabel maka butir kuesioner tersebut tidak reliabel.

Tabel 2. Hasil Uji Reliabilitas

\begin{tabular}{|c|l|c|c|c|}
\hline No & \multicolumn{1}{|c|}{ Variabel } & $\begin{array}{c}\text { Nilai Cronbach's } \\
\text { Alpha }\end{array}$ & r-tabel & Kesimpulan \\
\hline 1 & Kompensasi SDM(X1) & 0,606 & 0,294 & Reliabel \\
\hline 2 & Motivasi (X2) & 0,773 & 0,294 & Reliabel \\
\hline 3 & Lingkungan Kerja(X3) & 0,760 & 0,294 & Reliabel \\
\hline 7 & Kinerja (Y) & 0,655 & 0,294 & Reliabel \\
\hline
\end{tabular}

Sumber : Data yang diolah penulis, 2021

Berdasarkan tabel diatas dapat dilihat bahwa nilai Reliabilitas Cronbach's Alpha $>$ dari r-tabel mempunyai tingkat reabilitas yang tinggi, dan sehingga dapat disimpulkan bahwa questioner variabel Kompensasi SDM, Motivasi, lingkungan kerja dan Kinerja dinyatakan dapat diterima atau reabel.

\subsection{Analisis Regresi Linier Berganda}

Berdasarkan data primer yang dikumpulkan dari penyebaran questioner penulis akan menganalisis dengan perhitungan regresi linier berganda untuk menunjukkan pengaruh antara variabel bebas yaitu kompensasi $\operatorname{SDM}\left(\mathrm{X}_{1}\right)$, motivasi kerja $\left(\mathrm{X}_{2}\right)$, lingkungan kerja $\left(\mathrm{X}_{3}\right)$ dengan variabel terikat yaitu kinerja $(\mathrm{Y})$.

Tabel 3. Hasil Analisis Regresi Linier Berganda

\begin{tabular}{|c|c|c|c|c|c|c|}
\hline \multicolumn{7}{|c|}{ Coefficients $^{\mathrm{a}}$} \\
\hline \multirow{2}{*}{\multicolumn{2}{|c|}{ Model }} & \multicolumn{2}{|c|}{$\begin{array}{c}\text { Unstandardized } \\
\text { Coefficients }\end{array}$} & \multirow{2}{*}{$\begin{array}{c}\begin{array}{c}\text { Standardized } \\
\text { Coefficients }\end{array} \\
\text { Beta } \\
\end{array}$} & \multirow[t]{2}{*}{$\mathrm{T}$} & \multirow[t]{2}{*}{ Sig. } \\
\hline & & $\mathrm{B}$ & Std. Error & & & \\
\hline \multirow{4}{*}{1} & (Constant) & 1.406 & .605 & & 1.428 & .046 \\
\hline & Kompensasi & .339 & .295 & .316 & 2.503 & .025 \\
\hline & Motivasi & .201 & .167 & .194 & 2.223 & .037 \\
\hline & Lingkungan & .465 & 246 & 241 & 2.492 & .031 \\
\hline
\end{tabular}

a. Dependent Variable: kinerja

Maka persamaan regresi yang didapatkan adalah sebagai berikut:

$$
Y=1.406+0,339 X_{1}+0,201 X_{2}+0,465 X_{3}+e
$$

Berdasarkan hasil Persamaan regresi linier berganda diatas dapat diartikan bahwa: Hasil bilangan konstanta diatas mempunyai nilai sebesar 1.406 (positif) menyatakan bahwa, jika kompensasi SDM $\left(\mathrm{X}_{1}\right)$, motivasi kerja $\left(\mathrm{X}_{2}\right)$, lingkungan kerja $\left(\mathrm{X}_{3}\right)$, maka nilai Kinerja Karyawan (Y) adalah sebesar 1.406. Artinya jika perusahaan tidak melakukan Kompensasi Finansial dan Kompensasi Non Finansial nilai Kinerja Karyawan pada dinas kebudayaan dan 
pariwisata sebesar 1.423 .

\subsection{Pengujian Hipotesis}

\subsubsection{Uji signifikansi parameter individual (uji statistik t)}

Uji t digunakan untuk mengetahui apakah variabel-variabel independen secara parsial berpengaruh nyata atau tidak terhadap dependen. Derajat signifikasi yang digunakan adalah 0,05. Apabila nilai signifikan lebih kecil dari derajat kepercayaan maka kita menerima hipotesis alternatif, yang menyatakan bahwa suatu variabel independen secara parsial mempengaruhi variabel dependen.

Tabel 4. Uji Hasil Analisis Uji Parsial (Uji t)

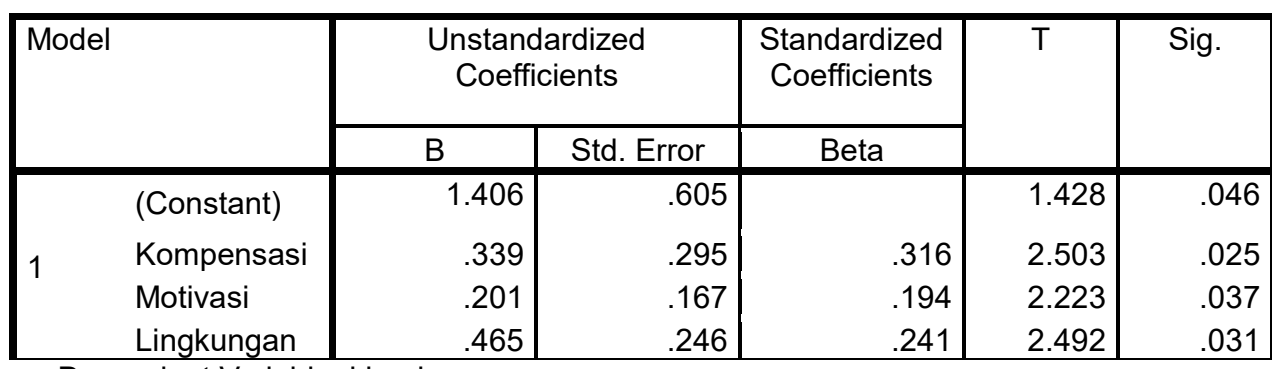

a. Dependent Variable: kinerja

SSumber : Data Primer yang diolah, 2021

Berdasarkan pada Tabel 4. dapat dijelaskan pengaruh dari masing-masing variabel independensi terhadap kinerja dilihat dari tingkat signifikan (probabilitas) arah tanda masingmasing variabel mengarah positif karena memiliki nilai $0,05(\alpha=5 \%)$. Variabel Kompensasi SDM, Motivasi Kerja dan Lingkungan Kerja berpengaruh terhadap Kinerja Pegawai.

\subsubsection{Uji simultan (uji f)}

Uji statistik F ini digunakan untuk mengetahui apakah variabel-variabel Independen secara simultan berpengaruh signifikan terhadap variabel Dependent. Derajat kepercayaan yang digunakan adalah 0,05 . Apabila nilai $\mathrm{F}$ tabel maka hipotesis alternatif yang menyatakan bahwa semua variabel independen secara simultan berpengaruh signifikan terhadap variabel dependen.

Tabel 5. Hasil Uji Simultan (Uji F)

\begin{tabular}{|rl|r|r|r|r|r|}
\hline Model & & Sum of Squares & Df & Mean Square & F & \multicolumn{1}{c|}{ Sig. } \\
\hline \multirow{2}{*}{1} & Regression & 2.687 & 3 & 4.448 & 8.865 & $.001^{\mathrm{a}}$ \\
& Residual & 6.424 & 41 & .432 & & \\
& Total & 9.111 & 44 & & & \\
\hline
\end{tabular}

a. Dependent Variable: Kinerja

b. Predictors: (Constant), Situasi, Kompetensi, Pengalaman, TBP, Independen, Etika

Sumber : Data Primer yang diolah, 2021

Berdasarkan Tabel 5 pengujian secara simultan $\mathrm{X}_{1}, \mathrm{X}_{2}, \mathrm{X}_{3}$ terhadap Y: Dari tabel diperoleh nilai $F_{\text {hitung }}$ sebesar 8.865 dengan nilai probabilitas $(\mathrm{sig})=0,001$. Nilai $F_{\text {hitung }}$ (5.980) $>\mathrm{F}_{\text {tabel }}(3,23)$, dan nilai sig. lebih kecil dari nilai probabilitas 0,05 atau nilai $0,001<0,05$, maka $\mathrm{H}_{\mathrm{a}}$ diterima, berarti menunjukkan bahwa adanya pengaruh yang positif dan 
signifikan Kompensasi SDM, Motivasi dan Lingkungan Kerja secara bersama-sama (simultan) terhadap varibel Kinerja pada dinas kebudayaan dan pariwisata Provinsi Sumatera Selatan.

\subsection{Pembahasan}

4.4.1 Pengaruh Kompensasi Sumber Daya Manusia terhadap Kinerja Pada Dinas Kebudayaan dan Pariwisata

Berdasarkan dari hasil uji koefisien $t$ hitung 2,503 dan $t$ Tabel 2,021, sehingga $t$ hitung 2,503 $>\mathrm{t}$ Tabel 2,021 (lebih Besar). Hal ini menyatakan bahwa kompensasi SDM signifikan terhadap kinerja ASN pada Dinas Kebudayaan dan Pariwisata Palembang. Hal ini terungkap sesuai dengan tabulasi hasil questioner variabel kompensasi SDM, nilai rata-rata tertinggi adalah penyataan Insentif berupa honor kegiatan yang diterima telah meningkatkan kinerja saya dalam bekerja. Menunjukkan bahwa ASN telah Insentif berupa honor kegiatan yang dapat telah meningkatkan kinerja ASN dalam bekerja. Hasil ini menerangkan bahwa kompensasi yang tepat dan diterima oleh pegawai maka akan meningkatkan kinerja pegawai pada kantor Dinas Kebudayaan dan Pariwisata Provisi Sumatera Selatan.

Hal ini sesuai dengan penelitian Leonard Adhi (2017) dan penelitain Hapitamala (2018) yang menjelaskan bahwa kompensasi berpengaruh terhadap kinerja karyawan. Malayu S.P Hasibuan (2002) dalam Asmayana (2018) mengatakan bahwa tujuan pemberian kompensasi antara lain adalah untuk kepuasan kerja karyawan yang nantinya akan menjaga stabilitas karyawan itu sendiri sehingga bisa menekan angka turn-over. Selain itu, karyawan juga akan terhindar dari pengaruh serikat buruh dan akhirnya hanya berkonsentrasi pada pekerjaannya saja. Disini dapat dilihat bahwa dengan pemberian kompensasi yang lebih layak dan diterima oleh pegawai karena sesuai dengan tenaga dan kemampuan yang dikeluarkan serta menghargai kerja keras pegawai, maka pegawai akan lebih bersikap professional dengan bekerja secara bersungguh-sungguh dan melakukan berbagai upaya agar bisa mencapai hasil kerja yang lebih baik sehingga kinerjanya bisa lebih meningkat.

Menurut Kadarisman (2012) kompensasi sangat penting dan berpengaruh terhadap perilaku dan kinerja karyawan. Kompensasi bermanfaat untuk menarik tenaga kerja atau karyawan baru, mempertahankan karyawan lama yang berkualitas, untuk memotivasi karyawan supaya bekerja dengan lebih baik, lebih giat, disiplin, dan mengembangkan kompetensinya demi tercapainya tujuan perusahaan. Organisasi /perusahaan perlu memberikan imbalan (reward) pada karyawan yang telah mengorbankan waktu, tenaga, kemampuan, dan keterampilan sehingga karyawan merasa puas karena usahanya tersebut dihargai

Kompensasi merupakan indikator tunjangan yang diterima telah ikut mendorong kesungguhan dalam melaksanakan tugas, tunjangan yang diberikan merupakan bentuk penghargaan organisasi kepada pegawai, insentif berupa honor kegiatan yang di terima telah meningkatkan kinerja saya dalam bekerja. Besarnya insentif honor kegiatan yang di terima sesuai dengan prestasi kerja dan keadilan dalam penerapan insentif, mendapat kesempatan untuk mengikuti program pendidikan, mendapat kesempatan untuk mengikuti diklat teknis untuk mengembangkan ketrampilan, dipromosikan dalam suatu jabatan karena prestasi kerja dan promosi yang diberikan akan mendorong untuk bersemangat dalam bekerja, telah dilakukan dengan baik dapat meningkatkan kinerja pegawai pada Kantor Dinas Kebudayaan dan Pariwisata Provinsi Sumatera Selatan. 


\subsubsection{Pengaruh motivasi kerja terhadap kinerja pada dinas kebudayaan dan pariwisata}

Untuk Variabel Motivasi Kerja uji koefisien $t$ hitung 2,223 dan $t$ tabel 2,021. Hal ini menyatakan bahwa $t_{\text {hitung }} 2,223>t_{\text {tabel }} 2,021$ bahwa Motivasi Kerja berpengaruh signifikan terhadap Kinerja pegawai pada Dinas Kebudayaan dan Pariwisata Provinsi Sumatera Selatan. Hal ini sesuai dengan tabulas hasil quesioner dengan penyataan "Bapak/ibu merasa puas dengan prestasi kerja yang telah dicapai selama ini89. Hal ini menunjukkan ASN sangat setuju dan termotivasi untuk berprestasi dalam menjalanakan pekerjaan nya yang telah dicapai selama ini.

Hal ini sesuai dengan penelitian I Wayan Juniantara dan I Gede Riana (2015), Dori Sandra Yudistira dan Febsri Susanti (2019) yang menyatakan bahwa motivasi berpengaruh positif dan signifikan terhadap kinerja. Suatu motivasi kerja yang ada dalam perusahaan sangat membantu perusahaan untuk mengetahui seberapa besar kemauan dan kemampuan karyawan dalam menyelesaikan suatu pekerjaan. Oleh karena itu melalui pemberian kompensasi yang sesuai dan terciptanya suatu motivasi kerja yang baik maka akan mampu meningkatkan kinerja Pegawai pada Dinas Kebudayaan dan Pariwisata Provinsi Sumatera Selatan.

Menurut Douglas \& Morris dalam Gabriela Rusua, dkk (2014), berpendapat bahwa indikator-indikator dari motivasi kerja ada empat yaitu perlu untuk pendapatan, Perlu untuk relaksasi, Perlu untuk keuntungan, dan Dorongan untuk bekerja. Dengan demikian dapat disimpulkan bahwa prestasi kerja dapat memberikan manfaat bagi perusahaan dan bagi pegawai itu sendiri .Adapun manfaat bagi pegawai prestasi kerja dapat menimbulkan perasaan puas pada diri mereka. Bagi organisasi prestasi kerja dapat memberikan manfaat yang sangat besar, karena cara ini dapat memberikan kemudahan pada perusahaan terutama hal-hal yang berkenaan dengan pengambilan keputusan organisasi dalam proses pencapaian tujuan.

\section{Kesimpulan}

Berdasarkan hasil penelitian yang dilakukan maka dapat disimpulkan bahwa Kompensasi Sumber Daya Manusia, Motivasi Kerja dan Lingkungan Kerja terhadap Kinerja Pegawai sebagai berikut :

1) Hasil hipotesis pertama $\left(\mathrm{H}_{1}\right)$ menunjukkan bahwa Kompensasi SDM berpengaruh positif dan signifikan terhadap kinerja Pegawai.

2) Hasil hipotesis Kedua $\left(\mathrm{H}_{2}\right)$ menunjukkan bahwa Motivasi Kerja berpengaruh positif dan signifikan terhadap kinerja Pegawai.

3) Hasil hipotesis Ketiga $\left(\mathrm{H}_{3}\right)$ menunjukkan bahwa Lingkungan Kerja berpengaruh positif dan signifikan terhadap kinerja Pegawai.

\section{Referensi :}

AA. Anwar Prabu Mangkunegara 2013. Manajemen Sumber Daya Manusia Perusahaan. Bandung: Remaja Rosdakarya

AlifFurqoni Aulia Wisudawan dan Eka Afnan Troena. 2013. Pengaruh Kompensasi Finansial dan Non Finansial Terhadap Motivasi Kerja Karyawan Universitas Bra- wijaya Hotel Kota Malang, Jurnal Ilmiah, Fakultas Ekonomi dan Bisnis Universitas Brawijaya. 
Amsrong, Michael \& Murlis, Helen. 2003. Reward Man- agement (Manajemen Imbalan) Sirategi dan Praktik Renumerasi, Alih Bahasa : Ramelan. Edisi-I.Gramedia. Jakarta.

Aribowo, Risky Novianto. 2011. Pengaruh,Kepemimpinan, Motivasi dan Lingkungan Kerja Fisik Terhadap Kinerja Karyawan Pada CV. Karya Mina Putra Rem- bang Devisi Kayu. Skripsi Universitas Diponegoro.

Bangun,Wilson (2012), Manajemen Sumber Daya Manusia,Jakarta: Erlangga

Eko Widodo Suparno. 2015. Manajemen pengembangan sumber Daya manusia. Yogyakarta : pustaka belajar.

Fauzi, F., Dencik, A. B., \& Asiati, D. I. (2019). Metodologi Penelitian untuk manajemen dan akuntansi. Jakarta: Salemba Empat.

Fitriani Risni, Adam Idris, Aji Ratna Kusuma (2014). Pengaruh Ramunerasi,motivasi dan kepuasan kerja terhadap kinerja pegawai dikantor pengadilan tinggi agama samarinda : Jurnal Administrative Reform, (online), vol 2, No 3, (http://ejournal.ar.mian.fisipunmul.ac.id) diaskses 16 maret 2018.

Ghozali, Imam. 2011. Aplikasi Analisis Multivariate dengan Program IBM SPSS 19, Cet V. Semarang: UNDIP

Hartatik, Indah P. (2014) Buku Praktis mengembangkan SDM cetakan pertama. Jogjakarta :Laksana.

Hasibuan Melayu 2013. Manajemen Sumber Daya Manusia. Jakarta: PT Bumi Aksara Handoko dalam Septawan dkk 2014, Manajemen Personalia dan Sumber daya Manusia.Yogyakarta : BPFE.

Kasmawati, 2014. Pengaruh Lingkungan Kerja Terhadap Kinerja Karyawan Pada PT Sermani Steel Makassar. Makassar: Skripsi Mangkunegara. Anwar Prabu. 2013. Manajemen Sumber Daya Manusia Penerbit Alfabeta

Kasmir. 2016. Manajemen Sumber Daya Manusia. Jakarta: Rajawali Pers

Khasanah Iswatin (2015) dengan judul pengaruh kompensasi manajemen eksekutif terhadap kinerja keuangan perusahaan : jurnal Akuntansi Unesa,(online) Vol 3, No 2,(http://ejournalmahasiswa.unesa.acid) diakses 16 maret 2018

M . Kadarisman (2012). Manajemen Kompensasi. Jakarta : Raja Grafindo Persada

Murti, H., \& Srimulyani, V A, (2013). Pengaruh Motivasi Tehadap Kinerja Pegawai Dengan Variabel Pamediasi Kepuasan Kerja pada PDAM Kota Madiun. Manajemen Jurnal, Vol 1-No 1, 10-17.

Nugroho Edi,(2013). Pengaruh pemberian kompensasi terhadap kinerja karyawan pada kantor Bmkg Stasiun Geofisika Manado: jurnal manajemen dan bisnis,(online),Vol1,No1(http://ejournal.unima.ac.id/index.php/jmb/article/vie $\quad$ w.249) diakses 16 maret 2018.

Radian Danu Saputra. 2017. Pengaruh Kompetensi Karyawan dan Lingkungan Kerja terhadap kinerja karyawan PT. PLN (persero) Distribusi Lampung. Lampung: Skripsi

Rivai, H. Veithzal dan Sagala, Ella Jauvani. (2009).Manajemen Sumber Daya Manusia Untuk Perusahaan Edisi 2. Jakarta: PT. Raja Grafindo. 
Rury Riana Rahmah. 2014. Pengaruh Kompetensi Terhadap Kinerja Karyawan Pada PT Asuransi Umum Bumiputra Muda 1967. Bogor: Skripsi

Sandhira, A F, Rahardjo, Kusdi, Utami, H N, (2013). Pengaruh Motivasi Terhadap Kinerja Karyawan (Studi Karyawan PT. PLN (Persero) Distribusi Jawa Timur Area Pelayanan dan Jaringan Malang).1-11

Sedarmayanti. 2007. Manajemen Sumber Daya Manusia. Reformasi Birokrasi dan Manajemen Pegawai Negeri Sipil. Bandung: PT. Refika Aditama

Sofyandi Herman (2013) manajemen Sumber daya manusia (pertamaed, Vol. cetalkan Pertama) Yogyakarta Graha ilmu.

Sugiyono. 2014. Metode Penelitian Kuantitatif, Kualitatif,dan R\&D. Bandung.

\section{Copyrights}

Copyright for this article is retained by the author(s), with first publication rights granted to the journal.

This is an open-access article distributed under the terms and conditions of the Creative Commons Attribution license (http://creativecommons.org/licenses/by/4.0/) 